Seed ecology of dust seeds in situ: a new study technique and its application in terrestrial orchids

Rasmussen, Hanne Nina; Whigham, Dennis F.

Published in:

American Journal of Botany

Publication date:

1993

Document version

Publisher's PDF, also known as Version of record

Citation for published version (APA):

Rasmussen, H. N., \& Whigham, D. F. (1993). Seed ecology of dust seeds in situ: a new study technique and its application in terrestrial orchids. American Journal of Botany, 80, 1374-1378. 
Seed Ecology of Dust Seeds in Situ: A New Study Technique and Its Application in Terrestrial Orchids

Author(s): Hanne N. Rasmussen and Dennis F. Whigham

Source: American Journal of Botany, Vol. 80, No. 12 (Dec., 1993), pp. 1374-1378

Published by: Botanical Society of America

Stable URL: http://www.jstor.org/stable/2445665

Accessed: $29 / 10 / 2014$ 10:07

Your use of the JSTOR archive indicates your acceptance of the Terms \& Conditions of Use, available at

http://www.jstor.org/page/info/about/policies/terms.jsp

JSTOR is a not-for-profit service that helps scholars, researchers, and students discover, use, and build upon a wide range of content in a trusted digital archive. We use information technology and tools to increase productivity and facilitate new forms of scholarship. For more information about JSTOR, please contact support@jstor.org. 


\title{
SEED ECOLOGY OF DUST SEEDS IN SITU: A NEW STUDY TECHNIQUE AND ITS APPLICATION IN TERRESTRIAL ORCHIDS ${ }^{1}$
}

\author{
HANne N. RASMussen ${ }^{2}$ ANd DenNis F. WhighaM ${ }^{3}$ \\ Smithsonian Environmental Research Center, Edgewater, Maryland 21037.
}

\begin{abstract}
A method is described by which seeds of terrestrial orchids are sown and retrieved in the field under almost natural conditions. For the first time it is possible to conduct a quantitative study of orchid germination in situ and observe seasonal growth and mortality of seedlings. The technique has also enabled us to investigate the relation between the site where the seeds are sown, the availability of an appropriate fungus to infect the seeds, and seedling establishment in the soil. Five local species were studied. Corallorhiza odontorhiza, Goodyera pubescens, and Galearis spectabilis all began to germinate in May-June, after 23-30 weeks in the soil. These species differed in their dependency on infection at germination time, but none of the seedlings developed beyond the point of rupturing the testa except when infected. Seeds of Liparis lilifolia and Tipularia discolor did not germinate within the first 12 months of the experiment. The implications and potential uses of this field sowing technique for further studies and for other kinds of minute seeds are discussed.
\end{abstract}

The study of seed ecology in minute seeds, such as those found in Orchidaceae, Orobanchaceae, and certain Ericaceae, is seriously impeded by the fact that "dust" seeds are so difficult to handle individually and almost impossible to trace in soil. Often the germination of such seeds is dependent on symbiotic or parasitic relationships with other organisms. Young seedling stages (protocorms) of terrestrial orchids live as parasites on fungi and remain underground for several weeks or months, perhaps years, after germination. Thus very little is known about the fate of orchid seeds from the time when they leave the capsule until seedlings are large enough to be seen above ground. There is no exact information concerning the season of germination and the rate of seedling development.

Most information about germination requirements stems from experiments in vitro, but it is not known how closely laboratory observations resemble the processes in situ. Many species germinate readily on a nutrient agar within weeks or months of incubation at $20 \mathrm{C}$, especially if inoculated with a compatible fungus (e.g., Borris, 1969; Clements, Muir, and Cribb, 1986). Others require cold stratification of some length (Borris, 1969; Ballard, 1987, 1990; Coke, 1990; Rasmussen, 1992; Stoutamire, 1992). It is not known whether these physiological differences contribute to a difference in germination timing in nature.

Protocorms of terrestrial orchids in the northern temperate zone have bene found in a number of cases, but the exact age of these seedlings is always unknown. Most have been found in spring (Fabre, 1856; Bernard, 1899; Ames, 1922; Fuchs and Ziegenspeck, 1926a, b, 1927b; Zeigenspeck, 1936; Curtis, 1943; Mrkvicka, 1990), fewer

\footnotetext{
1 Received for publication 16 March 1993; revision accepted 7 June 1993.

The authors thank John O'Neill, Hal Horwitz, and Jacob Kagey for providing seeds for the study. This work was carried out while the first author held a Senior postdoctoral Fellowship at the Smithsonian Institution. This research was supported by a grant to HNR from the Danish Fulbright Commission and to DFW from the Smithsonian Environmental Sciences Program.

${ }^{2}$ Current address: Research Centre for Horticulture, Kirstinebjergvej 10, 5792 Aarslev, Denmark.

${ }^{3}$ Author for correspondence.
}

in summer or autumn (Irmisch, 1853; Ames, 1921; Fuchs and Ziegenspeck, 1927a, b; Zeigenspeck, 1936; Vermeulen, 1947; Möller, 1987, 1989, 1990), or even winter (Irmisch, 1853). These observations suggest that seeds of many species lie dormant in the soil through winter with germination occurring in spring.

Mycorrhizal fungi appear to be required for successful germination and establishment of orchid seedlings in the soil. Such fungi have been isolated from roots or spontaneous seedlings in a range of orchid species. When compatibility is tested by co-culture of seedlings and fungi in vitro it is often found that there is no direct correspondence between the fungi living in the roots of older plants and those active in germination (Hadley, 1970; Warcup, 1975). Even if a fungal strain does form effective mycorrhiza in vitro, it is not certain that it would be effective as a seedling mycorrhiza in a natural substrate. It would thus be desirable to identify the fungi that actually support germination in the soil.

A technique for sowing and retrieving seeds in situ is needed for answering these questions. There are no published reports of successful field sowings where it has been possible to continuously record the status of the seeds and seedlings. However, we have a number of personal reports from colleagues who have tried to develop a technique but have experienced difficulties in retrieving any seeds, dissolution of materials used to retain the seeds in the soil, and lack of germination.

In this paper we describe a technique that we have used for directly observing germination in soil. Since the technique may be very useful for other investigators we believe that a preliminary report at this stage is warranted.

\section{MATERIALS AND METHODS}

Experiments were carried out in forests around the Smithsonian Environmental Research Center in Edgewater, Maryland. We used five locally occurring species: Corallorhiza odontorhiza (Willd.) Nuttall, Goodyera pubescens (Willd.) R. Br., Galearis spectabilis (L.) Rafin., Liparis lilifolia (L.) L. C. Rich. ex Lindl., and Tipularia discolor (Pursh) Nuttall. Seed capsules were harvested 

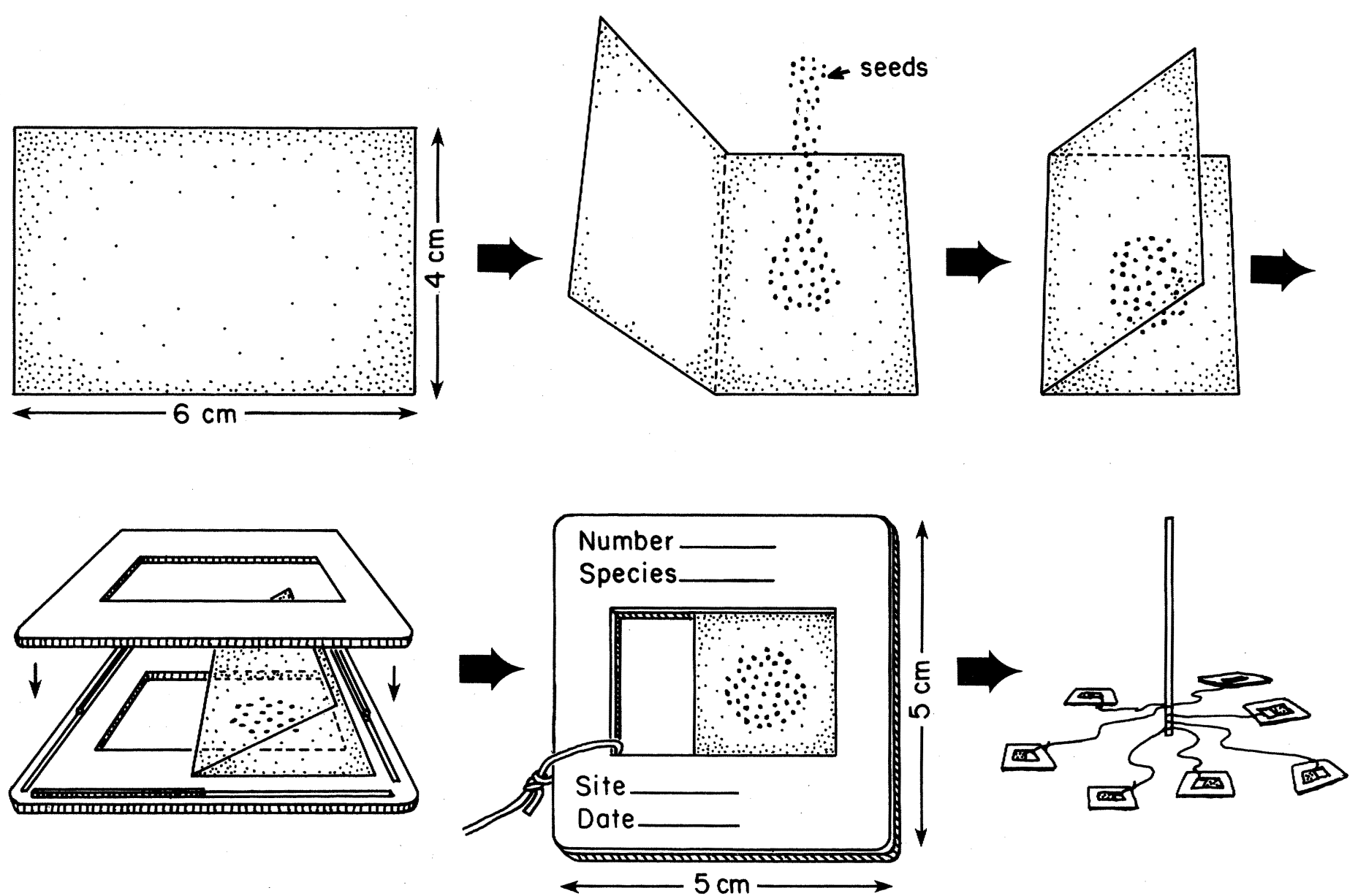

Fig. 1. Construction of a seed packet for sowing minute seeds. Seeds are placed on a piece of nylon plankton netting which is folded once and mounted into a glassless slide mount. The packets are buried in the soil attached by nylon strings to a pole for easy retrieval.

locally or in adjacent areas (Virginia) in September-November 1991. The seeds were separated from capsule tissue and stored in the relatively dry air of the laboratory at room temperature until use. Storage time was about 4 weeks (Liparis), 7 weeks (Corallorhiza, Tipularia), and 8 weeks (Goodyera, Galearis).

The seeds were sown in packets constructed from 40$\mathrm{mm} \times 60-\mathrm{mm}$ rectangles of plankton netting (Nutex no. 35 ) and $2-\mathrm{mm} \times 2-\mathrm{mm} \times 36-\mathrm{mm}$ plastic slide mounts without glass (Gepe). The pore size of the netting ( $35 \mu \mathrm{m})$ was chosen so as to retain the seeds while allowing minor soil organisms, bacteria, and fungal hyphae to pass through. Seeds were placed on the netting that was folded once and affixed in the slide mount (Fig. 1). The fold spanning the frame gives the otherwise unyielding nylon netting some flexibility, which is essential once the seedlings begin to develop. Identification information was written on the white side of the frame with a black permanent marker (Fisherbrand).

Sets of 11 seed packets were buried in the soil in November 1991 for retrieval at intervals of 6 weeks. Nine replicate sets of 11 packets were produced for Goodyera and Tipularia, and six sets for Corallorhiza, Galearis, and Liparis. The sets with Goodyera and Tipularia were distributed evenly in three localities, those of Corallorhiza in two, and those of Galearis and Liparis in a single lo- cality. Each set was placed in a ca. $45-\mathrm{cm} \times 50-\mathrm{cm}$ plot, which was marked with a bamboo pole, and the seed packets were tied to the pole with bright green nylon monofilament line to ensure retrieval (Fig. 1). The packets were buried with the white face of the slide frames up, and lightly covered with soil and leaf litter, which was kept in place by covering the plot with galvanized chicken wire secured with wire pegs.

After collection, the seed packets were rinsed, drained on paper towels, the slide mount opened, and the netting unfolded. In preliminary tests we found that the netting itself was not a good background for counting the seeds because of the strong interference from the mesh pattern. Instead, the inner side of the netting was lightly pressed onto the surface of a plate of water agar $(12 \mathrm{~g}$ purified agar (Sigma) in 1 liter distilled water) to transfer the seeds/ seedlings. They were retained by the slightly sticky agar surface where they could easily be counted under a stereo microscope with transmitted light.

\section{PRELIMINARY RESULTS}

After 12 months in the soil (November 1991 to December 1992) the seed packets were still intact and remained attached to the pole. No packets had been lost, and the text written on the frames was still clear. A few 
of the slide mounts had fractured edges but none had damages that affected the retention of the netting. Also in a few cases, the netting had been pushed out of intact slide mounts. However, the netting remained folded and still contained the seeds/seedlings.

Six weeks after being placed in the soil the packets contained bacteria and fungal hyphae, small mineral soil particles, and small animals up to the size of nematodes. The seeds in the packets were imbibed and showed no sign of deterioration, but the seed coats of Goodyera showed signs of loosening, i.e., the cells tended to break away from each other at the middle lamella when the seeds were covered with a coverslide for microscopic examination. No seed packet of any species harvested within the first 24 weeks of the study contained any germinated seeds.

Liparis and Tipularia-The seeds of Liparis and Tipularia failed entirely to germinate during the observation period but they appeared to be largely intact after 12 months in the soil.

Goodyera - In the beginning of May (24 weeks after sowing) swelling embryos began to split the testas of Goodyera. Germination was $31.1 \% \pm 4.7 \%$ (mean $\pm \mathrm{SE}$ ). In later retrievals there were consistently germinated seeds in the packets (Fig. 2) but the mean germination fluctuated, indicating a large degree of variance within each plot, but there were no obvious differences between sites. By the beginning of December germination averaged $50.0 \%$ $\pm 8.7 \%$.

The level of mycorrhizal infection varied in the seedlings of Goodyera, both among sowing sites and among individual seed packets in each plot. Seedlings that lacked the yellowish-tinged base indicative of mycorrhizal infection did not grow beyond $0.35 \mathrm{~mm}$ in length, hardly longer than the imbibed embryo (Fig. 2). Seedlings with obvious infection were found only in packets from the two sites where Goodyera occurs naturally (Fig. 3). The most rapidly growing seedlings in a random sample had reached a length of $1.5 \mathrm{~mm} 45$ weeks after sowing. Mortality of seeds and seedlings was first observed at 36 weeks after sowing and accounted for ca. one-third of the individuals. By the end of the observation period mortality averaged $42.9 \% \pm 7.9 \%$.

Galearis - In the beginning of June, 23 weeks after sowing, split seed coats were first recorded in Galearis. Germination averaged $7.4 \%( \pm 2.2 \%)$ initially and remained near that level, averaging to $10.2 \%( \pm 2.5 \%)$ by late October, 44 weeks after sowing. The seedlings only just split the testa but were apparently not infected, and there has been no further growth of the seedlings up to 62 weeks after sowing.

Corallorhiza - The germination in Corallorhiza varied with site. No germination was observed in the seed packets that had been placed in a ca. 50-year-old forest where Liparis, Galearis, and Tipularia but no Corallorhiza occurred. In contrast, germinated seeds were observed from mid-June, after 30 weeks in the soil, in the three plots that were placed in mature forest within an established population of Corallorhiza. Germination ranged from $6.5 \%$ to $48.8 \%$. Later retrievals showed large within-site variation, and 54 weeks after sowing the germination ranged from $3.2 \%$ to $89.1 \%$ in the three plots. All seedlings were apparently infected (Fig. 4). Great variation in growth was observed among individual seedlings, the largest seedling recorded was $15.9 \mathrm{~mm}$ long 54 weeks after sowing (Fig. 5). Mortality of seedlings and ungerminated seeds averaged $19.0 \%( \pm 6.0 \%)$ of the sample 36 weeks after sowing and $26.4 \%( \pm 7.2 \%) 54$ weeks after sowing.

A typical Rhizoctonia was isolated from seedlings of Goodyera. This strain closely resembled those that previously have been isolated from young plants in the same area and which have proven highly effective for seedling growth in vitro (unpublished data). From seedlings of Corallorhiza we isolated a strain with clamp connections (Fig. 6) that grows densely and slowly on potato-dextrose agar and dextrose-peptone agar.

\section{DISCUSSION}

The practical result of this study is a workable technique for studying germination and orchid seedling development in the field, but in principle the technique can be used in studies of any kind of small seeds. It can be concluded that a study of orchid seeds requires a long observation period and that the materials used for the seed packets were sufficiently durable for such a study. Minor disturbances to the seed packets, which were probably due to the activities of rodents and earthworms, did not result in the loss of data from any seed packet.

Apart from the exclusion of plant roots and larger sized animals such as millipedes and earthworms, the seed packets constituted a fairly natural environment for the seeds. Obviously, however, the sowing technique does not allow the seeds to trickle down through the soil strata as they might under natural conditions, and the sowing density may be above normal in the packets.

The method can be further improved. We suggest that the great variability between packets within plots can be reduced by standardizing the amount of soil and litter that is placed on top of the seed packets. For statistical purposes, the number of seed packets retrieved with each sampling of a site should be increased. By knowing the approximate time when germination can be expected, much effort can be saved during the dormant season, and more replicates and closer retrieval dates can be invested into examining the season of germination and growth. A regulated amount of seed in each packet, for instance measured by weight, would allow an estimate to be made of the number of seeds lost to complete decomposition. With the present method, only seeds with some fragments

Figs. 2-6. 2. Germination in Goodyera pubescens. Sample from the end of July, 36 weeks after sowing. Seedlings with a ruptured testa (arrows). Bar $=1 \mathrm{~mm}$. 3. Seedlings of Goodyera that have started to grow and which are infected in the basal part (arrows), sample from end of July, 36 weeks after sowing. Bar $=2 \mathrm{~mm}$. 4. Seedlings of Corallorhiza, all infected at base (arrows), sample from end of July, 36 weeks after sowing. Bar $=2 \mathrm{~mm}$. 5. Great variation in seedling sizes (smallest seedlings indicated by arrows), the largest being $15.9 \mathrm{~mm}$ long. November, 54 weeks after sowing. Bar $=10 \mathrm{~mm}$. 6. Endophyte from seedlings of $C$. odontorhiza, with clamp connections (arrows). Bar $=0.1 \mathrm{~mm}$. 


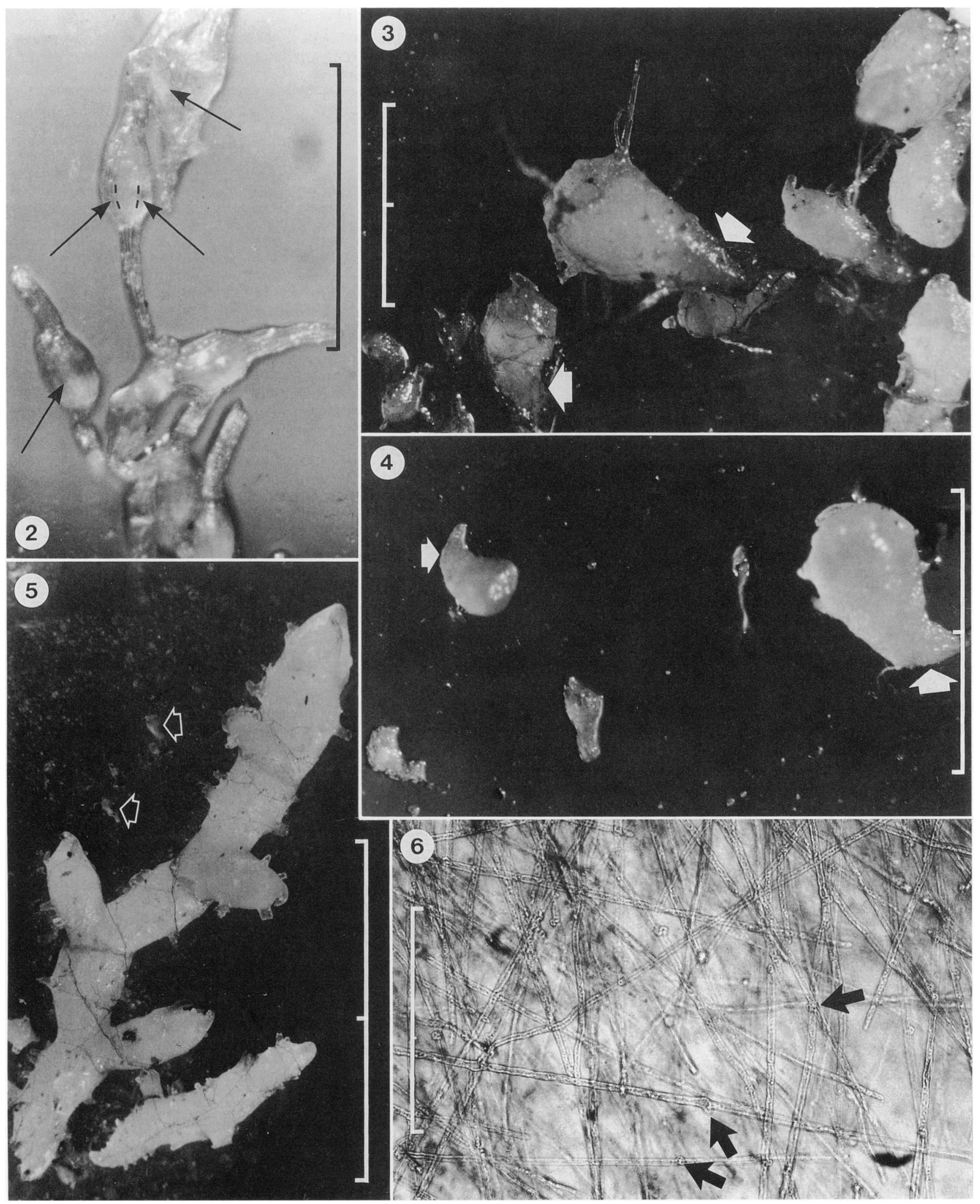


remaining are taken into account when seed fate is recorded. This may result in an underestimation of mortality.

In some of the later retrievals (after about 9 months in the soil) there was a problem with removing the seeds and seedlings from the netting because they were tied to it by an extensive network of fungal hyphae. It was necessary to scrape the material off the netting with a razor blade. This procedure allows for most of the material to be retrieved, but rough handling could rupture the seed coat of the imbibed seeds, which might then be erroneously recorded as germinated.

The perspectives of applying the method more widely are intriguing. For the first time, we will be able to isolate fungi that with certainty are involved in seedling development and to compare germination and fungal association patterns under different conditions, and at different sites. The seasonal rhythm of germination and seedling growth can be investigated within an exact time frame and on a statistical basis. The weathering and microbial decomposition of testa as well as the development in reserve nutrients during dormancy and germination in the soil can be analyzed. The agar surface on which the samples were transferred for recording could also be used as a substrate for the fungi and bacteria that were associated with the seeds at the time of retrieval. Isolation and identification of these organisms would give further information about the microhabitat that surround germinating orchid seeds.

All of the biological results described here need confirmation in repeated experiments. Although the timing of germination appears to be in spring and early summer in three of the species, we cannot tell whether the germination is correlated with season or with the time spent in the soil. Goodyera and Galearis germinated also in the absence of a compatible fungus, but infection was required for further seedling development. In contrast, seeds of Corallorhiza apparently required the presence of an appropriate fungus for germination. All seedlings of this species showed mycorrhizal infection. These data suggest that the species differ in germination strategy and that site and orchid/fungus specificity play a major role in the establishment of the seedlings.

\section{LITERATURE CITED}

AMES, O. 1921. Notes on New England orchids I. Spiranthes. Rhodora 23: $73-85$.

- 1922. Notes on New England orchids II. The mycorrhiza of Goodyera pubescens. Rhodora 24: 37-46.

BALLARD, W. W. 1987. Sterile propagation of Cypripedium reginae from seeds. American Orchid Society Bulletin 56: 935-946.
1990. Further notes on Cypripedium germination. In C. E. Sawyers [ed.], North American native terrestrial orchid propagation and production, 87-89. Brandywine Conservancy, Chadds Ford, PA.

BERnARD, N. 1899. Sur la germination du Neottia nidus-avis. Comptes Rendues des Seances de la Academie de Science (Paris) 128: 12531255.

BorRIs, H. 1969. Samenvermehrung und Anzucht europäischer Erdorchideen. Proceedings of the 2nd European Orchid Congress, 7478, Paris.

Clements, M. A., H. Muir, AND P. J. CribB. 1986. A preliminary report on the symbiotic germination of European terrestrial orchids. Kew Bulletin 41: 437-445.

COKE, J. L. 1990. Aseptic germination and growth of some terrestrial orchids. In C. E. Sawyers [ed.], North American native terrestrial orchid propagation and production, 90-91. Brandywine Conservancy, Chadds Ford, PA.

Curtis, J. T. 1943. Germination and seedling development in five species of Cypripedium L. American Journal of Botany 30: 199206.

Fabre, J.-H. 1856. De la germination des Ophrydées. Annales des Sciences Naturelle, IV Série, Botanique 5: 163-186, plate 11.

FuCHS, A., AND H. ZIEGENSPECK. 1926a. Entwicklungsgeschichte der Axen der einheimischen Orchideen und ihre Physiologie und Biologie I. Cypripedium, Helleborine, Limodorum, Cephalanthera. Botanisches Archiv 14: 165-260.

$\longrightarrow$, AND - 1926b. Entwicklungsgeschichte der Axen der einheimischen Orchideen und ihre Physiologie und Biologie II. Listera, Neottia, Goodyera. Botanishes Archiv 16: 360-413.

, AND - 1927a. Entwicklungsgeschichte der Axen der einheimischen Orchideen und ihre Physiologie und Biologie III. Botanishes Archiv 18: 378-475.

- AND - 1927b. Entwicklung, Axen und Blätter einheimischer Orchideen, IV. Botanishes Archiv 20: 275-422.

HADLEY, G. 1970. Non-specificity of symbiotic infection in orchid mycorrhiza. New Phytologist 69: 1015-1023.

IRMISCH, T. 1853. Beiträge zur Biologie und Morphologie der Orchideen. Ambrosius Abel, Leipzig.

Möller, O. 1987. Vom Samenkorn bis zur ersten echten Knolle: das Protocormstadium von Orchis mascula. Die Orchidee 38: 297-302. 1989. Die Samenkeimung, das Protocormstadium und der Aufwuchs der Orchis militaris. Die Orchidee 40: 29-32.

. 1990. Beobachtungen und Bemerkungen über den Wuchs der Dactylorhiza maculata. Die Orchidee 41: 22-26.

MrkvickA, A. C. 1990. Neue Beobachtungen zu Samenkeimung und Entwicklung von Liparis loeselii (L.) Rich. Mitteilungsblatt des Arbeitskreis heimische Orchideen Baden-Württemberg 22: 172-180.

RASMUSSEN, H. N. 1992. Seed dormancy patterns in Epipactis palustris (Orchidaceae): requirements for germination and establishment of mycorrhiza. Physiologia Plantarum 86: 161-167.

Stoutamire, W. P. 1992. Seed germination of Cypripedium acaule and Cypripedium reginae (Orchidaceae) in axenic culture. Ohio Journal of Science 92(2): 16.

Vermeulen, P. 1947. Studies on Dactylorchids. Schotanus and Jens, Utrecht.

WARCUP, J. H. 1975. Factors affecting symbiotic germination of orchid seed. In F. E. Sanders, B. Mosse, and P. B. Tinker [eds.], Endomycorrhizas, 87-104. Academic Press, London.

ZIEGENSPECK, H. 1936. Orchidaceae. In O. von Kirschner, E.. Loew, C. Schröter [eds.], Lebensgeschichte der Blütenpflanzen Mitteleuropas, I, 4. Eugen Ulmer, Stuttgart. 